\title{
The Effect of Free Cash Flow-based Agency Costs on Dividends in Companies Listed on the Tehran Stock Exchange (TSE)
}

\author{
${ }^{1}$ Abbas Rostamlu \\ 2Reza Pirayesh \\ ${ }^{3}$ Kazem Hasani

\begin{abstract}
Abbas Rostamlu, Master of Accounting, Abdul Rahman Sufi Razi Institute of Higher Education
Department of Accounting, Zanjan, Iran; abbas7rostamloo@yahoo.com

Reza Pirayesh, Assistant Professor of Management and Accounting, University of Zanjan, Iran; r-pirayesh@znu.ac.ir Kazem Hasani, Master of Accounting, Islamic Azad University of Zanjan, Department of Accounting
\end{abstract} \\ Zanjan, Iran; kazem10hasani@yahoo.com
}

\section{Doi:10.5901/mjss.2016.v7n4s2p131}

\section{Abstract}

\begin{abstract}
This study investigated the effect of free cash flow-based agency costs on dividends in a sample of 73 companies listed on the Tehran Stock Exchange during a period of five years from 2007 to 2011. The free cash flow-based agency costs were measured through several metrics including free cash flow, financial leverage, corporate growth, profitability, firm size and stock risk. The data were analyzed through multiple regression and panel method. The results of the statistical analysis concerning the research hypotheses in SPSS and E-VIEWS demonstrated that free cash flow and dividend corporate growth had an inverse effect on dividend. Moreover, the results suggested that financial leverage, profitability, firm size and stock risk left direct effects on dividend.
\end{abstract}

Keywords: agency costs, free cash flow, corporate growth, profitability, stock risk, dividend

\section{Introduction}

One of the financial reports made available to investors is cash flow statement. Cash flow statement refers to a data transfer tool for assessing the ability to repay debt, liquidity and financial flexibility. The essential concept involved in cash flow statement is free cash flow (FCF) as a criterion to measure the performance of companies, which can have an effect on the market price of stocks. It should also be noted that the old accounting criteria such as earnings per share and return on assets alone cannot represent the firm's performance. These measures should rather be applied in addition to free cash flows. That is because it is very difficult to conceal and manipulate free cash flows, whereas earnings are frequently manipulated by CEOs.

Free cash flows represent a cash obtained by a company after making the expenses for maintenance or development of assets. Free cash flows can have important applications for shareholders in assessing the financial health of firm. It should be noted that all individuals are naturally looking to increase their personal interests. Therefore, managers may also participate for reasons such as retention, rewards and other factors, intentionally or unintentionally, in a situation to render the company favorable. Conflicts of interest between managers and owners (shareholders) can aggravate the risk of unreliable information. One of the factors playing a role in a conflict between shareholders and owner is how to pay cash to shareholders as dividends. The payment of dividends in cash considered less frequently leads to the company's liquidity. According to Jensen (1986), if managers are looking to grow their companies in any way possible, they invest the free cash flows in projects with negative net present value, followed by earnings management to eliminate losses from investment profits. In such projects, the cash funds are distributed between shareholders for the benefit of shareholders and improves the company's situation. Dividend is a major output cash flows is many companies. Investors have different motivations in buying shares. The manager can adopt appropriate policies to realize the main corporate objective, i.e. Maximizing the corporate profits and ultimately maximize shareholder's wealth. As financial leverage increases, there will be gradual decline in the amount of cash flow and therefore the manager's choices on how to use the cash (Bulow, 1999). This study sought to understand the impact of free cash flow-based agency costs and dividend in companies listed on Tehran Stock Exchange. 


\section{Literature Review and Theoretical Background}

\subsection{Free cash flow}

There have not been provided a single definition of free cash flow. The theory of free cash flow was first proposed by Jensen (1986). In addition, the theoretical analysis of agency costs was carried out by Jensen concerning free cash flows. In this theory, free cash flow is defined as "the residuals of cash flows after deducting the cash necessary to invest in projects with positive net present value". These projects are long-term investments whose expected input present value of cash flows are higher than the expected output present value of cash flows. Obviously, the cost of capital rate is used to discount in calculating the present value. As defined by Jensen (1986), free cash flow is determined by the following formula:

Model (1) $F C F_{t}=C F O_{t}-$ Investment $_{t}^{+}$

Where:

$F_{C F}$ : Free cash flows of the firm in period t: $\mathrm{CFO}_{t}$ Cash from from business operations during period t: Investment $t_{t}^{+}$Free cash flow needed for investment in projects with expected positive net present value in period $\mathrm{t}$

Following Jensen (1986), there were several studies conducted to deliver

various definitions to free cash flows. Accordingly, free cash flow measures are defined as follows: Accordingly, free cash flow measures are defined as follows:

Model (2)

$$
\operatorname{FCF}_{i, t}=\left(I N C_{i, t}-T_{A X_{i, t}}-\operatorname{INTEXP}_{i, t}-P S D I V_{i, t}-\operatorname{CSDIV}_{i, t}\right) /_{A_{i, t-1}}
$$

Where:

$F C F_{i, t}$ : Free cash flow of company $\mathrm{i}$ in year $\mathrm{t}: I N C_{i, t}$ Operating profit before depreciation for company $\mathrm{i}$ in year $\mathrm{t}$ : $T A X_{i, t}$ Total taxes payable in company i in year t: INTEXP $P_{i, t}$ Interest expense payable for company i in year t: $P S D I V_{i, t}$ Payable preferred shareholders profit for company $\mathrm{i}$ in year t: $\operatorname{CSDIV}_{i, t}$ Payable ordinary shareholders profit for company $\mathrm{i}$ in year t: $A_{i, t-1}$ Total book value of assets in for company i in year t-1

Copland (1989) proposed the following definition for free cash flow: "It is the operating profit after tax deduction plus non-cash expenses after deducting investments in property, machinery, equipment and other assets".

Model (3) $F C F_{t}=E_{t}+N C C_{t}-\Delta W C_{t}-\Delta F A_{t}$

Where:

$F C F_{t}$ : Free cash flows of the firm in period t: $E_{t}$ Profits after tax deduction the firm in period t: $N C C_{t}$ Non-cash expenses such as depreciation, bad receivables, etc. of the enterprise during period t: $\Delta W C_{t}$ Expansion in working capital of the enterprise during period t: $\Delta F A_{t}$ Increase in gross book value of the enterprise's total fixed assets in period $t$ (Copland, 1989).

\subsection{Dividends}

Dividend policy is one of the most important issues in financial management, because dividends reflect the cash payments made by a major company and one of the most important choices facing managers today. Managers must decide what amount of profits are distributed and what amount to be reinvested in the company in the form of retained earnings. Despite the fact that dividend payments will directly benefit shareholders, it affects the company's ability to accumulate profits in order to take advantage of growth opportunities. In addition, the policy on the stock market, entails data content where any changes will have new information for shareholders. Considering their expectations, each investor buys the shares of a company whose stock dividend policy is desirable. The dividend proposed by the board usually contains information about the expectations of managers about the future profitability of the company. Dividend policy is also one of the concepts affected by the costs of representation. There are generally two different views on the relationship between dividends and agency costs. Firstly, dividend is a solution to reduce agency costs between managers and shareholders. Secondly, dividends are a substitute for agency problems. Furthermore, the theoretical and empirical research findings indicate a significant relationship between ownership structure and representation costs (Nouresh et al., 2009). 


\subsection{Stock risk}

Risks and returns on investment and financing are always together and cannot be considered separately, because investment decisions are adopted always based on the relationship between risk and return. Investors should always bear in mind the risk in their investment decisions. Risk is an outcome of the difference between the actual output and the expected return on investment. Most investors assume that the actual return is lower than expected returns. However, the greater the risk volatility the greater the return (Tehrani and Noorbakhsh, 2003). The following equation is used to calculate stock risk:

$$
\begin{aligned}
& \text { Model (4) } \delta_{i}=\sqrt{\frac{\sum\left(r_{i}-\bar{r}\right)^{2}}{n}} \\
& \delta_{i} \text { : Deviation of actual returns or stock risks } r_{i} \text { : Actual return } \bar{r} \text { : Average market return } n \text { : Number of periods. }
\end{aligned}
$$

\section{Literature Review}

Ghassan (2012) examined the impact of agency costs on dividends and leverage policy in 60 companies listed in Amman Stock Exchange during the period of 2007-2011. The results indicated that there is a significant negative relationship between free cash flow and dividend policy. There is a significantly positive relationship between free cash flow and financial leverage. There is a significantly positive relationship between financial leverage and dividend. There is a significantly negative relationship between growth opportunities and dividend. There is a significantly positive relationship between profitability and dividend. There is a significantly positive relationship between firm size and dividend. There is an insignificantly negative relationship between stock risk and dividend.

In a research, Amalando (2012) stressed on earnings management, evaluating and comparing the free cash flow in companies listed on the Stock Exchange of India. The results showed a significantly positive relationship between earnings management and free cash flow.

Utami and Inanga (2011) explored the impact of agency costs of free cash flow on dividend policy and financial leverage in 45 companies listed on the Malaysian Stock Exchange in the period of 1994-2007. The results of data analysis suggested there is a significantly negative relationship between free cash flow and dividend. There is a significantly positive relationship between free cash flow and financial leverage. There is a significantly positive relationship between financial leverage and dividend. There is a significantly negative relationship between growth opportunities and dividend. There are insignificantly positive relationships between profitability and dividend; firm size and dividend, stock risk and dividend.

Wang et al. (2011) explored the impact of free cash flow and agency costs on performance in companies listed on the Taiwan Stock Exchange. The results showed that free cash flow resulting from the efficiency of internal operations can lead to optimal performance of the company. The agency costs leave a major negative impact on corporate performance and stock returns. In addition, the findings are indicative of the fact that free cash flows are in a significant positive relationship with corporate performance criteria.

Similarly, in Iran, Alavi Tabari et al. (2012) examined the issue of agency and pricing of independent audit service based on the hypothesis of free cash flows in companies listed on Tehran Stock Exchange. Audit fees for companies whose free cash flows and growth opportunities are higher than those whose free cash flows are low but growth opportunities are high. In addition, companies whose free cash flows and growth opportunities are high experience greater debt with greater audit fees in average. According to the results, however, an increase in the dividends reduced the agency problem arising from free cash flows.

Setayesh and Zolfaghari (2011) investigated the effect of free cash flows and investment opportunities on debt/dividend ratios in companies listed on Tehran Stock Exchange. The results of statistical analysis on the hypotheses showed that there is a significantly negative relationship between free cash flow and debt ratios. Nonetheless, there is no significant relationship between investment opportunities and debt ratio. In addition, there is no significant relationship between free cash flow and dividend payout ratio. However, there is a significantly positive relationship between investment opportunities and dividend policy.

Moradi et al. (2011) explored the dividend policy from the perspective of agency theory. The results indicated that the proportion of non-executive members of the Board of Directors, fixed asset structure, business risk and debt ratio were in a negative relationship between dividend payout ratio. Furthermore, there was a significantly positive relationship between profitability, liquidity and ownership of board members with dividend payout ratio. Firm size and profitability opportunities are not effective in dividend payout ratio. 


\section{Hypotheses}

There were 6 hypotheses expressed as follows:

First hypothesis: Free cash flow affects dividends in companies listed on TSE.

Second hypothesis: Financial leverage affects the distribution of dividends in companies listed on TSE.

Third hypothesis: There is a relationship between corporate growth and dividends in companies listed on the TSE.

Fourth hypothesis: There is a relationship between profitability and dividends in companies listed on the TSE.

Fifth hypothesis: There is a relationship between firm size and dividends in companies listed on the TSE.

Sixth hypothesis: There is a relationship between stock risk and dividends in companies listed on the TSE.

\section{Methodology}

This was an applied research in terms of objective. Moreover, it adopted a descriptive, retrospective approach. The data were collected from the databases of Tadbirpardaz and Rahavard Novin as well as SEO's Research Development and Islamic Studies1.

In hypotheses testing, the relationship between independent and dependent variables was determined through multivariate regression. Moreover, the Durbin-Watson test was employed to analyze the correlation between the error terms of the model, while the analysis of variance was used to assess the estimation. The significance level was $5 \%$ to accept or reject the hypothesis. All statistical data were analyzed using SPPS and E-VIEWS. Additionally, student t-test was used for partial regression coefficients and the significance of the regression model was determined through Fisher (F) at confidence level of 95\% (5\% error).

\section{Population, Sampling Method and Sample Size}

With respect to the subject matter, the type of information required and its application, the population of this research covered all companies listed on the Tehran Stock Exchange during 5 fiscal years from 2007 to 2011. The subjects in this study were selected using systematic elimination based on the following criteria:

1- Excluding banks, financial institutions, investment and leasing companies.

2- To comply with the comparability, the fiscal year ended March 21.

3- Companies did not change fiscal years during 2007-2011.

4- By the end of 2007, the companies were listed on Tehran Stock Exchange and never left TSE during 20072011.

5- The financial statements of the companies are available.

Considering the above criteria, a total of 73 companies, including the companies listed in Tehran Stock Exchange, were selected as samples.

\section{Operational Definition of Variables}

Dividends: The study measured the ratio of dividends using the following equation:

$$
D I V_{i, t}=\frac{D P S_{i, t}}{E P S_{i, t}}
$$

$: D I V_{i, t}$ The dividends distributed among the majority shareholders: $D P S_{i, t}$ Dividend per share: $\mathrm{EPS}_{\mathrm{i}, \mathrm{t}}$ Earnings per share (Setayesh and Zolfaghari, 2011, pages: 71-87.

Financial leverage: This study involved debt-to-equity ratio. (Setayesh and Zolfaghari, 2011, Pages 71-87)

Corporate growth: The Q-Tobin ratio was used to calculate the corporate growth by dividing the market value of the stock plus the book value of debt plus book value of the acquired assets (Heidarpour and Mostofi, 2009, pages 20-37).

Profitability: Profit ratio is obtained from the special net profit after tax deduction to equity (Setayesh and Zolfaghari, 2011, pages: 71-87.

Firm size: Because of the reliability of balance sheet items in the present study, the natural logarithm of total assets on the balance sheet date was used to measure the firm size (Sayah and Salehabadi, 2005).

Free cash flows: The free cash flows in this study were derived based on Wong's model (2010) through the following equation:

\footnotetext{
1 http:// www.rdis.ir
} 
$F C F_{t}=\frac{O C F_{t}-\text { Tax }_{t}-\text { IExp }_{t}-\text { CDiv }_{t}-\text { PDiv }_{t}}{\text { Sales }_{t}}$

$F C F_{i, t}$ : Free cash flow of company $\mathrm{i}$ in year t: $O C F_{i, t}$ Operating cash flow of company $\mathrm{i}$ in year $\mathrm{t}: \operatorname{Tax}_{i, t}$ Corporate income tax expense at t: $\operatorname{Exxp}_{i, t}$ Interest payments at t: $C D i v_{i, t}$ Common stock dividend at t: PDiv ${ }_{i, t}$ Preferred stock dividends at t: Sales $_{i, t}$ Net sales of the company at $\mathrm{t}$ :

Stock risk: The following equation is used to calculate stock risk:

$\delta_{i}=\sqrt{\frac{\sum\left(r_{i}-\bar{r}\right)^{2}}{n}}$

$\delta_{i}$ : Deviation of actual returns or stock risks $r_{i}$ : Actual return $\bar{r}$ : Average market return $n$ : Number of periods.

The research hypotheses were verified through the regression equation as follow:

$D I V_{i, t}=a_{\mathrm{o}}+\beta_{1} F_{C F}+\beta_{\mathrm{p}} L E V_{i, t}+\beta_{\mathrm{\mu}} G R O W_{i, t}+\beta_{\mathrm{F}} P R F T_{i, t}+\beta_{\mathrm{o}}$ SIZE $_{i, t}+\beta_{\xi} R I S K_{i, t}+\varepsilon_{i, t}$

$D I V_{i, t}$ : Dividend of company i year t: $F C F_{i, t}$ Free cash flow of company i in year t: $L E V_{i, t}$ Financial leverage of company $\mathrm{i}$ in year t: $G_{R O W_{i, t}}$ Growth of company i in year t: $P R F T_{i, t}$ Profitability of company i in year t: $S I Z E_{i, t}$ Size of company $\mathrm{i}$ in year $\mathrm{t}: R_{S} K_{i, t}$ Risk of company $\mathrm{i}$ in year t: $\alpha_{0}$ Intercept: $\beta_{1}, \ldots, \beta_{6}$ Coefficients of the regression model: $\varepsilon_{i, t}$ Disturbing element of regression model.

\section{Data Analysis and Research Findings}

This section first explores the descriptive data in the sample and then tests the hypotheses:

Figure 1: Descriptive statistics of research variables in the sample

\begin{tabular}{|c|c|c|c|c|c|c|}
\hline Description & Symbol of variables. & Mean & Median & SD & Minimum & Maximum \\
\hline Free cash flow & $F C F_{i, t}$ & 0.048 & 0.02 & 0.31 & -1.49 & 2.5 \\
\hline Financial leverage & $L E V_{i, t}$ & 1.19 & 1.75 & 11.75 & -190 & 41.58 \\
\hline Company growth & $G_{R O W}$ & 1.49 & 1.22 & 0.83 & 0.61 & 8.3 \\
\hline Profitability & $P R F T_{i, t}$ & 0.3 & 0.3 & 0.63 & -4.63 & 6.65 \\
\hline Company size & $S I Z E_{i, t}$ & 5.8 & 5.72 & 0.54 & 4.36 & 7.7 \\
\hline Dividend & $D I V_{i, t}$ & 0.57 & 0.62 & 0.5 & -0.6 & 5.53 \\
\hline Risk & $R I S K_{i, t}$ & 13.44 & 9.41 & 15.26 & 0.03 & 95.16 \\
\hline
\end{tabular}

Table (2) shows the results of tests carried out in the study variables. These tests include F-Limmer, significance regression, autocorrelation of regression model and testing hypotheses on dependent variable.

Figure (2). The results of regression analysis on research variables

$$
D I V_{i, t}=\alpha_{。}+\beta_{1} F C F_{i, t}+\beta_{\mu} L E V_{i, t}+\beta_{\mu} G R O W_{i, t}+\beta_{r} P R F T_{i, t}+\beta_{\Delta} S I Z E_{i, t}+\beta_{\vartheta} R I S K_{i, t}+\varepsilon_{i, t}
$$

\begin{tabular}{||l|c|c|c|c|c||}
\hline \hline Description & Symbol & Coefficient & T-statistic value & Confidence level & Variance inflation factor \\
\hline Free cash flow & $F C F_{i, t}$ & -0.056 & -2.97 & 0.003 & 1.58 \\
\hline Financial Leverage & $L E V_{i, t}$ & 0.021 & 5.44 & 000.0 & 1.08 \\
\hline Corporate growth & $G R O W_{i, t}$ & -0.067 & -6.3 & 000.0 & 1.13 \\
\hline Profitable & $P R F T_{i, t}$ & 0.239 & 7.8 & 000.0 & 1.62 \\
\hline Company size & $S I Z E_{i, t}$ & 0.083 & 2.3 & 0.022 & 1.23 \\
\hline Stock risk & $R I S K_{i, t}$ & 0.003 & 2.42 & 0.016 & 1.79 \\
\hline Durbin-Watson statistic & 1.97 & & $R^{2}$ & 0.501 \\
\hline Significance level of F statistic & 0.000 & & F statistic & 60.2 \\
\hline F-Limmer significance level & 0.54 & & F-Limmer statistics & 0.97 \\
\hline
\end{tabular}

F-Limmer test

According to the results in Table (2) for F-Limmer test, since the F-Limmer significance level is 0.54 , greater than 0.05 , it is not appropriate to adopt the panel data approach. Hence, it is better to employ the data compilation method. 
To investigate the lack of correlation in the regression model, the Durbin-Watson test was used. According to Table (2), the value of Durbin-Watson statistic is 1.97. In this regard, according to the number of observations ( $\mathrm{N}=73$ ) and number of explanatory variables $(K=6)$, the values of $\mathrm{dU}$ and critical $\mathrm{dL}$ at 95 percent confidence level were 1.80 and 1.45 , respectively.

As a result, the equation 4- $d U d<>d u$ is established. Hence there was no extreme autocorrelation between the regression model errors, which is proved as one of the essential regression hypotheses concerning the fitted model.

\section{Hypotheses Testing}

\subsection{First hypothesis}

$H_{0}$ :Free cash flow does not affect dividends in companies listed on TSE.

$H_{1}$ : Free cash flow affects dividends in companies listed on TSE.

According to the results in table above, free cash flow with a factor of $\beta=0.056$ at confidence level of $95 \%$. Therefore, hypothesis $H_{0}$ is rejected and hypothesis $H_{1}$ is proven, regarding the significant effect of free cash flow on dividend policy. Moreover, the negative $\beta$ coefficient suggested that the free cash flow had an inverse effect on dividends.

\subsection{Second hypothesis}

$H_{0}$ : Financial leverage on the distribution of dividends in companies listed on the exchange effect.

$H_{1}$ : Financial leverage affects the distribution of dividends in companies listed on TSE.

According to the results in table above, financial leverage with a factor of $\beta=0.021$ at confidence level of $95 \%$. Therefore, hypothesis $H_{0}$ is rejected and hypothesis $H_{1}$ is proven, regarding the significant effect of financial leverage on dividend policy. Moreover, the positive $\beta$ coefficient suggested that financial leverage had a direct effect on dividend.

\subsection{Third hypothesis}

$H_{0}$ :There is no relationship between corporate growth and dividends in companies listed on the TSE.

$H_{1}$ : There is a relationship between corporate growth and dividends in companies listed on the TSE.

According to the results in table above, corporate growth with a factor of $\beta=0.067$ at confidence level of $95 \%$. Therefore, hypothesis $H_{0}$ is rejected and hypothesis $H_{1}$ is proven, regarding the significant effect of corporate growth on dividend policy. Moreover, the negative $\beta$ coefficient suggested that the corporate growth had an inverse effect on dividends.

\subsection{Fourth hypothesis}

$H_{0}$ :There is no relationship between profitability and dividends in companies listed on the TSE. $H_{1}$ : There is a relationship between profitability and dividends in companies listed on the TSE.

According to the results in table above, profitability with a factor of $\beta=0.239$ at confidence level of $95 \%$. Therefore, hypothesis $H_{0}$ is rejected and hypothesis $H_{1}$ is proven, regarding the significant effect of profitability on dividend policy. Moreover, the positive $\beta$ coefficient suggested that the profitability had a direct effect on dividends.

\subsection{Fifth hypothesis}

$H_{0}$ :There is no relationship between firm size and dividends in companies listed on the TSE.

$H_{1}$ : There is a relationship between firm size and dividends in companies listed on the TSE.

According to the results in table above, firm size with a factor of $\beta=0.0083$ at confidence level of $95 \%$. Therefore, hypothesis $H_{0}$ is rejected and hypothesis $H_{1}$ is proven, regarding the significant effect of firm size on dividend policy. Moreover, the positive $\beta$ coefficient suggested that form size had a direct effect on dividends.

\subsection{Sixth hypothesis}

$H_{0}$ :There is no relationship between stock risk and dividends in companies listed on the TSE.

$H_{1}$ :There is a relationship between stock risk and dividends in companies listed on the TSE. 
According to the results in table above, risk with a factor of $\beta=0.003$ at confidence level of $95 \%$. Therefore, hypothesis $H_{0}$ is rejected and hypothesis $H_{1}$ is proven, regarding the significant effect of stock risk on dividend policy. Moreover, the positive $\beta$ coefficient suggested that stock risk had a direct effect on dividends.

\section{Conclusions and Suggestions}

This study involved several criteria including free cash flow, financial leverage, growth, profitability, firm size and risk as agency costs of free cash flow. Hence, this study intended to evaluate the effect of free cash flow-based agency costs on dividend in the form of six hypotheses under a span of 2007-2011 in companies listed on Tehran Stock Exchange, seeking to reduce agency costs of free cash flow and consequently reduce conflicts of interest between owners and managers of the company.

Figure (3): Summary of results for research hypothesis

\begin{tabular}{|c|l|c|c|}
\hline Hypothesis & Description & Result of hypothesis & Type of relationship \\
\hline First & $\begin{array}{l}\text { Free cash flow affects dividends in companies listed } \\
\text { on TSE. }\end{array}$ & Approved & Approved \\
\hline Second & $\begin{array}{l}\text { Financial leverage affects the distribution of } \\
\text { dividends in companies listed on TSE. }\end{array}$ & Approved \\
\hline Third & $\begin{array}{l}\text { There is a relationship between corporate growth } \\
\text { and dividends in companies listed on the TSE. }\end{array}$ & Inverse \\
\hline Fourth & $\begin{array}{l}\text { There is a relationship between profitability and } \\
\text { dividends in companies listed on the TSE. }\end{array}$ & Approved \\
\hline Fifth & $\begin{array}{l}\text { There is a relationship between firm size and } \\
\text { dividends in companies listed on the TSE. }\end{array}$ & Direct \\
\hline Sixth & $\begin{array}{l}\text { There is a relationship between stock risk and } \\
\text { dividends in companies listed on the TSE. }\end{array}$ & Approved & Direct \\
\hline
\end{tabular}

\section{Practical Recommendations Based on the Results of Hypotheses Testing}

A) According to the results of the first hypothesis, all companies accepted in Tehran Stock Exchange are suggested to reduce agency costs resulting from conflicts of interest between owners and managers by distributing the free cash flow to shareholders through dividends.

B) With respect to the second hypothesis, the major shareholders involved in the annual general meetings are recommended to pay more attention to dividend ratio. If the corporate debt is high, then distribute lower amount of dividend.

C) According to the results of the third and fourth hypotheses, all users of financial information in particular corporate executives, shareholders and the government for the privatization of state-owned companies considering specific investment opportunities are proposed to adopt the results.

D) According to the results of the fifth hypothesis, the users of financial statements including financial analysts are advised to decide on the dividends with regard to the firm size. Usually small companies face more problem than large companies in their financing. It is recommended that they finance their cash dividends from cash flow from operations.

E) According to the results of sixth hypothesis, the company executives are recommended to watch their decisions on dividend policy. If a company wants to perform change the company's dividend policy unlike the special features of the company's stock risk, investment opportunities and so on, there will be a negative market reaction. Therefore, providing complete justification information by the management for public enlightenment and stakeholders will be essential to the negative market reaction.

\section{Thematic Suggestions for Future Research}

1) The effect of free cash flow-based agency costs on internal capital market in stock distribution decisions

2) The relationship between free cash flow-based agency costs and financial flexibility

3) The relationship between free cash flow hypothesis and theory of business life cycle 


\section{References}

Bolou, G., (1999), "Comparing the effect of dividends and retained earnings on stock prices in the Tehran Stock Exchange" Master's thesis, University of Shahid Beheshti.

Tehran, Reza; Hesarzadeh, R., (2009), "The Impact of Free Cash Flow and restrictions on the financing of overinvestment and underinvestment ", Journal of Accounting Research, Issue III, pages: 67-50.

Javed Sheikh, M., et al., (2012), "free cash flow: The importance of the use and its role in earnings management ", Journal of Accounting and Auditing, first year, second edition, pages: 20-1.

Heidarpour, Sage, Mostofi, H., (2009), "jurisprudence of the relationship between Tobin's Q ratio and refined economic value, companies listed in the Tehran Stock Exchange ", Journal of Financial Accounting, First Year, Issue 1, Pages: 37-20.

Rezvani Raz, Karim, Haghighat, H., (2005), "The relationship between free cash flows and the amount of debt taking into account the investment opportunities and the size of the companies listed in Tehran Stock Exchange ", Journal of Research, Issue 5, Pages: 57-50.

Rezvani Raz, Karim, Haghighat, H., (2005), "The relationship between free cash flows and the amount of debt taking into account the investment opportunities and the size of the companies listed in Tehran Stock Exchange ", Journal of Research, Issue 5, Pages: 107-92.

Setayesh, MH; Zolfaghari, M., (2011), "The impact of free cash flow and investment opportunities based on debt and sharing the profits of companies listed on Tehran Stock Exchange ", Journal of Tehran Stock Exchange, Issue 15, Pages: 87-71.

Setayesh, MH; Zolfaghari, M., (2011), "The impact of free cash flow and investment opportunities based on debt and sharing the profits of companies listed on Tehran Stock Exchange ", Journal of Tehran Stock Exchange, Issue 15, Pages: 51-29.

Setayesh, MH et al., (2011), "An Analysis of factors affecting capital structure from the perspective of agency theory" Shiraz University of accounting developments, Volume III, Issue I, pages: 89-55.

Sayah, S, Saleh Abad, A., (2005), "Principles of Financial Engineering and Risk Management" Tadbir Pardaz Computer Group.

Alavi Tabari, Seyed Hosseini et al., (2012), "The issue of representation of pricing and free cash flow hypothesis based testing services independent auditor" Journal of Accounting and Auditing Reviews, Volume 19, Issue 2, Pages: 122-97.

Moradi, J. et al., (2011), "dividend policy from the perspective of agency theory" Journal of Accounting and Audit, Issue XII, pages: 1-25.

Mehrani, S, Bagheri, Ali, 2009, "Effects of free cash flow and institutional shareholders on earnings management in listed companies in Tehran Stock Exchange ", Accounting Research, Issue 2, Pages: 71-50.

Nourush, I. et al., (2009), "the relationship between corporate governance mechanisms and agency costs of listed companies in Tehran Stock Exchange" Journal of Accounting, Number 1, Pages: 27-4.

Hashemi, Seyed Abbas, Kamali, E., (2010), "The effect of a gradual increase in financial leverage, the free cash flow and Growth Management firms listed in the Tehran Stock Exchange "Journal of Accounting, First Year, Issue 2, Pages: 115-95.

Yahyazadeh, Mahmoud Emad, Mehdi, (2011), "The relationship between free cash flow, profitability status and the dividends of listed companies in Tehran Stock Exchange "Stock Exchange Quarterly, Issue 14, Pages: 201-187.

Amalendu, B, (2012), "A Comparative Study between Free Cash Flow and Earnings Management", Reader in Commerce; Fakir Chad College under University of Calcuta, Diamond Harbour.

Chen, Y., and Chen, L., (2007), "Income Smoothing, Information Uncertainty, Stock Returns and Cost of Equity", a dissertation for the degree of doctor of philosophy, The University of Arizona, Vol. 33, No. 1, pp: 345-370.

Copeland, T. E., Weston, (1989), "Financial Theory and Capital Policy", Boston, MA, Addison-Wesley.

Ghassan, A. (2012), "Measurement of Impact Agency Costs Level of Firms on Dividend and Leverage Policy: An Empirical Study", Interdisciplinary Journal of Contemporary Research in Business, VOL 4, NO 9, PP: 234-243.

Griffin, A., and H. Lont \& Yuan sun, (2009), "Agency Problems and Audit fees: Further Tests of the Free Cash Flow Hypothesis", Journal of Finance Vol 1, pp: 1-35.

Jensen M. C., (1986), "Theory of the Firm: Managerial Behavior, Agency Costs, and Capital Structure", J Finance Econ 3, PP: 305-360.

Jensen M. C. and Meckling W. H, (1976), "Theory of the Firm: Managerial Behavior, Agency Costs, and Capital Structure", J Finance Econ 3, pp: 305-360.

Len, K., and Poulsen, A, (1989), "Free Cash Flow and Stock Holder Gains in Going Private Transactions", Journal of finance 44, PP: 774-789.

Utami, S. R. and Inanga, E. L., (2011), "Agency Costs of Free Cash Flow, Dividend Policy, and Leverage of Firms in Indonesia", European Journal of Economics, Finance and Administrative Sciences, Issue 33, PP: 8-24.

Wang, G. Y., (2010), "The Impacts of Free Cash Flows and Agency Costs on Firm Performance", J. Service Science and Management, Issue 3, PP: 408-418. 